\title{
Is Science the Elixir of Life?
}

\author{
${ }^{1}$ Dr. S. Sushma Raj, ${ }^{2}$ Joel Saripelli, ${ }^{3}$ Dr. S.Sam Kumar \\ ${ }^{1}$ Assistant Professor, Department of English, GITAM Institute of Science, GITAM University \\ Visakhapatnam \\ ${ }^{2}$ Ex-Student, Wilmington University, New Castle, Delaware, U.S.A \\ ${ }^{3}$ Former Director, SOS Children's Villages of India, Nerellavasa colony, Bheemunipatnam, \\ Visakhapatnam
}

\begin{abstract}
The twenty first century has seen, gleaming skyscrapers hitting the skies, screaming technologies and jaw-dropping inventions. Modern man has brought the world to an awe inspiring threshold of the future. He has reached new and astonishing peaks of scientific success. He has produced machines that think and instruments that peer into the unfathomable ranges of interstellar space. He has built gigantic bridges to span the seas and towering buildings to kiss the skies. Yet, in spite of the spectacular strides he has made, the impact of science and technology on our social, mental, physical and environmental health can be devastating, if we don't apply science in the right perspective.
\end{abstract}

Keywords: Science, technology, industrialization, advancement, damage, nurture

\section{IS SCIENCE THE ELIXIR OF LIFE?}

Science has progressed very rapidly in the twenty first century. It has helped man in harnessing the forces of nature and has completely transformed the life of man on earth. With the help of science, man has conquered time and space. The nations of the world have come closer on account of instant communication and quick travel. However, Industrialization coupled with technological advancement has continued to affect the environment in a negative way. Complaints and issues associated with effects of technology are arising globally (Ausubel \& Sladovich, 1999). The impact of science and technology, which gave hundred sweet fruits to human culture and nature, has 'unconsciously' developed harmful effects like ecological imbalance, pollution, exhaustion of natural resources and stress on disadvantaged social groups.

No doubt, like many have said, science and technology has unimaginably revolutionized the world. Martin Rees, an astrophysicist says, "Science is key to earth's future" in an address at the British Science Festival September 12, 2013 in Newcastle, England. The electricity and the machines do all the drudgery for man, the wireless, television and internet enable instant communication, the ship and the airplane provide quick transport, the motor car and train offer easy conveyance, the refrigerator and air conditioning bring domestic comfort, the radar enables him to know the weather conditions much in advance. Using modern methods of agriculture man has increased food production and eliminated famines. Medical sciences have controlled diseases, eradicated epidemics and increased the span of life. Man has unlocked the energy from the atom. He can cause rainfall and produce a testtube baby. He can create a new species with the help of genetic engineering. So much more to add to this saga and there would be no end to it.

However science has brought with it, its damaging and destructive effects too. Man in his own greed to progress and develop himself has embraced science and technology so much that he has overlooked some essential factors that have led to a great damage to the environment and the planet in specific. Innumerable industries, townships, thermal plants, nuclear and electronic pollutions, greenhouse effects, ozone holes, heat islands, acid rains and all other things are his own actions, limitless and thoughtless. Scientists like Stephen Hawking has warned that by the end of 2100, life on earth will be questioned and will be endangered. Sir Martin Luther King powerfully remarked, 'We have genuflected before the god of science only to find that it has given us the atomic bomb, producing fears and anxieties that science can never mitigate'. Man has invented the Atom bomb and used it against his own race. The atomic bomb dropped on Hiroshima and Nagasaki in 1942 had the most 
lethal and noxious effects on human beings. The victims are yet to recover from the terrifying aftereffects of the incident. Man went on to develop powerful destructive weapons to safeguard himself. Martin Luther King said, "Our scientific power has outrun our spiritual power. We have guided missiles and misguided men". Missiles are kept ready in many parts of the world; even the slightest error may unleash a fatal war. The human race itself may be extinct one day. U Thant, Third Secretary-General of the United Nations has beautifully captured the ill-effects of science and technology in the lines below:

"As we watch the sun go down, evening
after evening,
Through the smog across the poisoned
waters of our native earth,
we must ask ourselves seriously
whether we really wish
some future universal historian on
another planet to say about us:
'With all their genius and with all their
skill,
They ran out of foresight and air and
food and water and ideas, 'or,
'They went on playing politics until their
world collapsed around them.'

Science by itself is not a panacea. If man uses it wisely, it serves him faithfully, if not it will certainly destroy him. According to Dr.Vannevar Bush "Science, by itself, provides no panacea for individual, social, and economic ills... But without scientific progress no amount of achievement in other directions can insure our health, prosperity, and security as a nation in the modern world." So much depends on how science is intelligently applied for peaceful purposes. Man must bear in mind, some of the slogans that keep echoing, such as, 'One earth, one environment', 'earth is a divine gift, save it, you cannot see another, mind it'. Hence the ownership rests on man and he is completely responsible for conserving, protecting and shielding our planet from the onslaught of erroneous application of science.

\section{CONCLUSION}

Our evolution in science and technology has involved some tincture of good with evil. Consequently, science by itself is not a universal solution. The New York Times, editorial (1986) quoted, "Technology, when misused, poisons air, soil, water and lives. But a world without technology would be prey to something worse..." Man must be aware of the detrimental consequences accompanied with wrong application of science and technology for his own greedy needs. He must rise to the occasion of protecting, upholding and nurturing 'nature' from eternal destruction.

\section{REFERENCES}

[1] Ausubel, J. \& Sladovich, A. (1999).Technological advancement. Washington D.C, US: National Academic publishers.

[2] Dewey John, Sigler A. Julius. (1997). Science, Technology and Society. University Press of America, pp. 129.

[3] Drell D. Sidney. (2007). Nuclear Weapons, Scientists, and the Post-Cold War Challenge: Selected papers on Arms Control. World scientific publishing Co. Pte. Ltd., U.S.A., pp. 7

[4] Lewis Tanya. (2013). Science Is Key to Earth's Future, Says Astrophysicist Martin Rees. Retrieved from http://www.livescience.com/39682-martin-rees-on-importance-of- science.html

[5] Martin Luther King Jr.(2010) Strength to Love. Fortress Press. U.S.A.

[6] Mc Connell John. (2011). Earth Day: Vision for Peace, Justice, and Earth care. Wipf and Stock publishers. U.S.A. 


\section{AUTHORS' BIOGRAPHY}

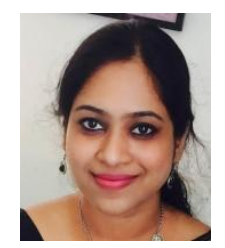

Dr. S.Sushma Raj, Assistant Professor in English, GITAM Institute of Science, GITAM University has about 13 years of teaching experience. Besides an M.A, M.Phil, and $\mathrm{PhD}$ in English, she also holds a degree in M.B.A (HRM). She published 17 articles in national and international journals and also the co-author of a book.

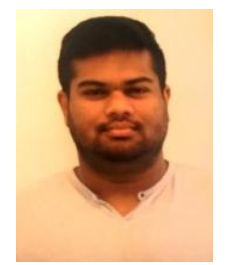

Mr. Joel Sushan Swaraj, has done his MS in Computer Science from Wilmington University. He is passionate about writing articles and poems in his leisure.

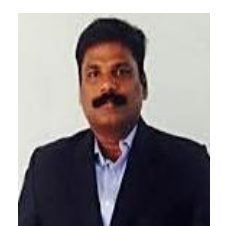

Dr. S.Sam Kumar, is a former Director of SOS Children's Villages of India. He has done his $\mathrm{PhD}$ from Andhra University and worked on atrocities on women. He has about 20 years of experience in various capacities in the NGO sector. He likes penning articles during his free time. He also delivers talks on a voluntary basis. 